"Determinants of corporate debt maturity: Evidence from the consumer goods sector in Vietnam"

\begin{tabular}{|c|c|c|}
\hline AUTHORS & \multicolumn{2}{|l|}{ Thi Van Trang Do (iD) } \\
\hline ARTICLE INFO & \multicolumn{2}{|c|}{$\begin{array}{l}\text { Thi Van Trang Do (2021). Determinants of corporate debt maturity: Evidence from } \\
\text { the consumer goods sector in Vietnam. Investment Management and Financial } \\
\text { Innovations, 18(3), 175-182. doi:10.21511/imfi.18(3).2021.16 }\end{array}$} \\
\hline DOI & \multicolumn{2}{|c|}{ http://dx.doi.org/10.21511/imfi.18(3).2021.16 } \\
\hline RELEASED ON & \multicolumn{2}{|l|}{ Friday, 27 August 2021} \\
\hline RECEIVED ON & \multicolumn{2}{|l|}{ Saturday, 12 June 2021} \\
\hline ACCEPTED ON & \multicolumn{2}{|l|}{ Monday, 23 August 2021} \\
\hline & \multicolumn{2}{|c|}{ 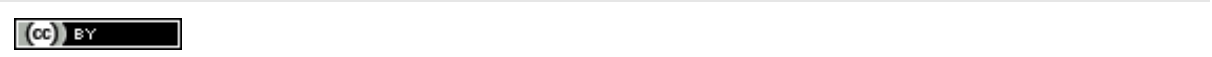 } \\
\hline LICENSE & \multicolumn{2}{|c|}{$\begin{array}{l}\text { This work is licensed under a Creative Commons Attribution } 4.0 \text { International } \\
\text { License }\end{array}$} \\
\hline JOURNAL & \multicolumn{2}{|c|}{ "Investment Management and Financial Innovations" } \\
\hline ISSN PRINT & \multicolumn{2}{|l|}{$1810-4967$} \\
\hline ISSN ONLINE & \multicolumn{2}{|l|}{$1812-9358$} \\
\hline PUBLISHER & \multicolumn{2}{|c|}{ LLC “Consulting Publishing Company "Business Perspectives" } \\
\hline FOUNDER & \multicolumn{2}{|c|}{ LLC "Consulting Publishing Company "Business Perspectives" } \\
\hline \multirow{2}{*}{ NUMBER OF REFERENCES } & & ニニ:- \\
\hline & NUMBER OF FIGURES & NUMBER OF TABLES \\
\hline 28 & 0 & 3 \\
\hline
\end{tabular}

(C) The author(s) 2021. This publication is an open access article. 


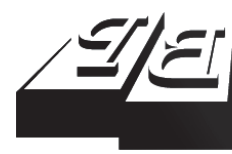

BUSINESS PERSPECTIVES

(O)

LLC "CPC "Business Perspectives" Hryhorii Skovoroda lane, 10, Sumy, 40022, Ukraine www.businessperspectives.org
Received on: $12^{\text {th }}$ of June, 2021 Accepted on: $23^{\text {rd }}$ of August, 2021 Published on: $27^{\text {th }}$ of August, 2021

(C) Thi Van Trang Do, 2021

Thi Van Trang Do, Ph.D., Department of Finance, Banking Academy, Vietnam.
Thi Van Trang Do (Vietnam)

\section{DETERMINANTS OF CORPORATE DEBT MATURITY: EVIDENCE FROM THE CONSUMER GOODS SECTOR IN VIETNAM}

\begin{abstract}
Debt maturity structure plays an important role in enterprises' capital structure policies, and debt maturity varies from industry to industry. The paper investigates the determinants that affect the debt maturity structure of listed firms in the consumer goods industry from 2009 to 2019. The data is collected from consumer goods companies listed on the Vietnam Stock Exchange. The feasible generalized least squares (FGLS) estimation is demonstrated to consider not only micro but also macroeconomic variables that have influenced the corporate debt maturity policy. The empirical results show that five microeconomic factors, such as capital structure, asset structure, asset liquidity, profitability, and firm size, have influenced the debt maturity and are statistically significant. Meanwhile, macroeconomic factors such as inflation rate and credit growth have significantly affected the corporate debt maturity. Finally, the paper provides some suggestions for financial managers on the optimal corporate debt maturity in the consumer goods sector and recommendations for policy-makers when implementing macroeconomic policies.
\end{abstract}

\section{Keywords}

JEL Classification debt maturity, consumer goods industry, listed companies, FGLS estimation, Vietnam Stock Exchange

\section{INTRODUCTION}

Capital structure has been studied both in previous literature and in empirical research in terms of optimal capital structure or target capital structure. They both pursue the same goals - to minimize the cost of capital and maximize shareholder wealth (Omar \& Saqer, 2020). An important factor of debt financing is the matching between the short- and long-term debts that is realized as the debt maturity structure. Regarding debt maturity theories, three major aspects have been considered such as the minimization of corporate tax, the information asymmetry, and the minimization of operating costs. To take advantage of tax, Brick and Ravid (1985) suggested firms to determine an optimal debt maturity structure. Long-term debt is the optimal choice to benefit from the tax shield when the term structure of interest is up-ward trend. Pour and Lasfer (2019) have shown the impact of corporate income tax on debt maturity structures by examining cross-country data. In high protection countries, firms have a propensity to have optimal debt maturities to benefit from financial leverage and decrease the cost of equity. The second aspect that needs to be taken into account is the liquidity and signaling theory. Fama (1990) recommends that the debt maturity structure implies that firms have incentives to disclose and supervise financial information and manage relevant contracts. Diamond (1991) proved that firms tend to choose short- 
term debt to avoid the bad credit rating when they optimize their debt maturity structure. However, firms need to consider the trade-off between high credit ratings and liquidity risk. The third aspect related to debt maturity focuses on contracting costs.

\section{LITERATURE REVIEW}

This section focuses on the corporate debt maturity literature, based on the economic theories and empirical findings. In modern finance, the theory of corporate debt policy has analyzed the advantages of debt financing and the relationship between short-term and long-term debt finance and why firms choose this source of finance over others.

The theory of Modigliani and Miller (1963) mentions the capital structure issue without taxes and with taxes. The advantage of a tax shield has been taken into account by internal managers, however, the incremental tax advantage would decrease if firms increased the portion of debt and the benefit of tax shields was less certain. In addition, the existence of personal taxes might decline the theoretical tax shield when considering corporate borrowing, the personal tax has differed as the gap between tax rates on capital gains and regular income. Nevertheless, Modigliani and Miller (1963) noticed the capital structure in a perfect world that the capital market is incomplete; therefore the corporate financing still may not be explained as limited. Alcock et al. (2012) mentioned the impact of financial leverage on debt maturity supported by matching principle while testing the data of Australian firms. Antoniou et al. (2006), Deesomsak et al. (2009), Lemma and Negash (2012), and Correia et al. (2014) found that financial leverage on debt maturity policy was significantly positive. However, Diamond (1991) showed no relationship between financial leverage and debt maturity.

For the theory of agency costs, an important component of corporate financing is the consideration of the appearance of agency costs. Jensen and Meckling (1976) showed the agency costs in relation to low-risk or high-risk assets. If firms increase the portion of assets financed by risky debt, their assets had intended to shift from low- to high-risk assets; it would increase the cost of agency. Myers (1977) examined the underinvestment problem and recommended that to reduce the underinvestment, firms be issued the short-term debt that matures before any investment opportunity to conduct growth options. Warner (1977), and Robichek and Myers (1966) debated whether financial distress costs incurred when the firms were in bankruptcy, even if they avoided bankruptcy. Leland and Toft (1996) revealed that short-term debt does not take the advantages of tax deduction as long-term debt. Thus, current debt would decrease asset substitution costs. To identify the optimal corporate debt structure, firms need to balance the financial leverage against financial risk and agency costs. More recently, Ozkan (2002) has provided evidence that agency-related costs had a negative influence on corporate debt maturity while testing the data set of non-financial companies in the UK. Amal and Terra (2011) stated that small-size firms intended to increase short-term debt to finance investment decisions. This leads to an increase in agency costs due to underinvestment and affects the benefits of shareholders. Based on the agency cost theory, a small-sized firm is difficult to assess the long-term debt because of the limitation of business scale and collaterals. This statement is supported by a study of Ozkan (2000) using data from 421 non-financial UK firms during 1983-1996 to determine the influence of firm size on debt structure. Furthermore, Antoniou et al. (2006), Cai et al. (2008), Deesomsak et al. (2009), Wang et al. (2010), and Fan et al. (2012) have explored the same finding of this relationship.

Jensen and Meckling (1976) developed a trade-off theory that expenses can signify the low costs of debts, benefitting from a tax shield, however, increases the cost of capital and reduces the firm value. Related to the cost of debt, firms need to consider the corporate debt maturity policy in order to minimize the interest cost. The trade-off model focuses on one period only by Myers (1977), whereas the dynamic trade-off model is highlighted in multiple periods by Fischer et al. (1989), consisting of the expenses of transactions and adjustments toward an optimal financial structure.

The pecking-order theory is applied by Myers, (1977) to choose the capital structure. Because of the asymmetric information, the internal financ- 
ing is priority and whether there is a requirement for external finance, issuing debt is prioritized before share issuance. For debt financing, it is necessary to identify the portion of short-term and long-term, in order to match with different types of assets. Furthermore, according to the Ross (1977) signaling theory, the growth of debt finance has a good signal for on-going business, and debt structure maturity had been taken into account. The market timing theory by Baker and Wurgler (2002) noticed that the volatility of equity markets heavily affected financing decisions: companies had intended to issue new shares whenever they were overvalued and repurchased them if share prices were low. As a consequence, it is not easy for firms to design an optimal capital structure and debt maturity. Nevertheless, recent empirical findings of Arnold (2013) suggested that it was only in the short run; a company might reach an optimal capital structure with the medium and long-term finance. That requires firms to appreciate the debt maturity structure in both medium and long term.

The matching principle was mentioned in a study by Alcock et al. (2012) that a company has a higher percentage of tangible assets that are willing to finance with long-term debts instead of short-term ones to reduce the distress cost. Ozkan (2002) and Majumdar (2010) have shown a positive correlation between tangible assets and debt maturity. Moreover, Ngo and Le (2021) have detected a positive impact of liquidity on corporate debt maturity while examining listed firms in Vietnam. Cai et al. (2008) and Deesomsak et al. (2009) highlighted that the effect of asset liquidity on debt maturity is significantly positive.

Empirical studies in this area have mainly been conducted in developed financial markets such as the United States or Eurozone where corporate debt can be traded in the financial market. The empirical results have shown that financial market characteristics have represented an important part of debt maturity decisions (Alcock et al., 2012). Antoniou et al. (2006) examined the factors affecting the debt maturity structure with the sample experience in France, Germany and the UK. These countries have the differences in financial markets and problems with legal issues related to corporate debt, which can affect the debt maturity structure. Alcock et al. (2012) evaluated the financing behavior of Australian firms while considering whether short- or long-term debts are financed by different types of assets and the determinants that affect the portion of different debt maturity. Moreover, the authors try to find whether the debt maturity choices have represented the financial market characteristics in different countries. Brick and Liao (2017) use a sample of US firms from CRSP/Compustat between 1985 and 2013 and found that level of cash holdings, financial leverage, international tax and bank loan covenants significantly affected corporate debt maturity. Besides, the choice of financing policy is considered in relation to the firm's characteristics and macroeconomic environment. González (2017) has explored the effect of firm- and country-level factors on the debt maturity structure for cross-sectional countries from 1995 to 2012. In this sample, the data from 171,892 companies in 39 countries were analyzed.. The findings implied that legal quality, bank concentration, and the role of a bank in the economy have influenced the financing policy of firms.

The aim of this paper is to investigate the determinants of corporate debt maturity based on the existing theories with the sample obtained from the Vietnamese consumer goods industry. Vietnam still is a frontier market, so much research has yet to be done on this issue, especially with a focus on the detailed sector due to unavailability of data. The consumer goods sector is one of the most important industries for economic growth of developing countries like Vietnam because they help to encourage domestic manufacturing and exports. Thus, they help to improve the gross domestic product of the economy. Furthermore, factors affecting debt maturity not only highlight microeconomic factors, but also macroeconomic determinants.

According to the literature related to the debt maturity structure, the hypotheses are formulated as follows:

\section{H1: A higher portion of debt will have a positive relationship with corporate debt maturity.}

H2a: A higher portion of tangible assets has a positive effect on corporate debt maturity. 
H 2b: Higher liquidity of assets has a positive effect on corporate debt maturity.

H3: A bigger company has a positive effect on corporate debt maturity.

H4: An increase in the rate of return has a positive effect on corporate debt maturity.

H5: Long-term asset maturity has a positive effect on corporate debt maturity.

H6: Corporate tax is positively correlated with corporate debt maturity.

H7a: Interest rate volatility has a positive effect on corporate debt maturity.

H7b: Gross domestic product has a positive impact on corporate debt maturity.

H7c: Inflation rate has a positive impact on corporate debt maturity.

H7d: Credit growth has a positive impact on corporate debt maturity.

\section{METHODOLOGY}

This section shows the relationship between the debt maturity structure and other factors based on the debt maturity theories. Debt maturity is taken into account by microeconomic and macroeconomic determinants that are mentioned below. This paper elaborates whether the microeconomic factors that reflect the characteristics and business cycle of specific industries have influenced the corporate debt maturity, especially in the consumer goods sector.

The data is collected from the FinnPro database, which not only contributes to the accounting data, but also provides macroeconomic indicators of companies listed on the Vietnam Stock Exchange. This paper aims to analyze the consumer goods industry that has shown rapid growth in recent years. Selected firms must have worked for at least eight consecutive accounting years during 2009-2019. When processing data, the missing observations of any variable in the model are eliminated. This paper explores the consumer goods industry list- ed on both Hanoi Stock Exchange and Hochiminh Stock Exchange; however, after processing data, the final sample included 78 consumer goods companies.

To evaluate the determinants of corporate maturity structure of consumer goods firms in Vietnam, the paper has applied the model as follows:

$$
\begin{aligned}
& L D R_{i t}=\beta_{0}+\beta_{1} T D R_{i t}+\beta_{2} T A N G_{i t}+ \\
& +\beta_{3} L I Q_{i t}+\beta_{4} S I Z E_{i t}+\beta_{5} A M R_{i t}+ \\
& +\beta_{6} G R O_{i t}+\beta_{7} R O E_{i t}+\beta_{8} T A X_{i t}+ \\
& +\beta_{9} G D P_{i t}+\beta_{10} I N F_{i t}+\beta_{11} C R E_{i t}+\varepsilon_{i t},
\end{aligned}
$$

where $L D R_{i t}$ is a corporate debt maturity structure that is determined by the value of long-term debt divided by the total debts of firm; $T D R_{i t}$ represents the financial structure of the firm measured through the debt ratio; $T A N G_{i t}$ denotes the asset structure, which is the percentage of long-term assets over total assets; $L I Q_{i t}$ identifies the liquidity of a firm, which is calculated by short-term assets divided by short-term liabilities; $S I Z E_{i t}$ is computed by the logarithm of total assets of a company; $A M R_{i t}$ is defined as asset maturity of a firm; $G R O_{i t}$ denotes the interest rate volatility; $R O E_{i t}$ is return on equity of a firm; $T A X_{i t}$ is mentioned as the tax rate, which is the total tax expense divided by total taxable income; there are three macroeconomic variables such as $G D P_{i t}$ - gross domestic product, $I N F_{i t}$ - inflation rate, and $C R E_{i t}$ - credit growth; $i$ represents different companies; $t$ is the time period from 2009 to 2019 .

\section{EMPIRICAL RESULTS}

As can be seen from Table 1, the descriptive statistics have been illustrated by both dependent and independent variables of consumer goods firms listed on the Vietnam Security Exchange. There is a huge difference in debt maturity of companies in the consumer goods sector. Some of them do not issue any debt, whereas others issue long-term debt up to $79 \%$ of the total debt. However, most firms issue short-term debts instead of long-term ones. Debt maturity is in line with the characteristics of the industry and with the countries that have the same economic conditions, such as Thailand and Malaysia (Deesomsak et al., 2009). 
Table 1. Descriptive statistics

\begin{tabular}{|c|c|c|c|c|c|}
\hline Variable & Obs & Mean & Std. Dev & Min & Max \\
\hline$\angle D R$ & 858 & 0.11677 & 0.15743 & 0 & 0.79784 \\
\hline$T D R$ & 858 & 0.47669 & 0.19748 & 0.01599 & 0.96692 \\
\hline TANG & 858 & 0.20729 & 0.15666 & 0.00062 & 0.77044 \\
\hline$\angle I Q$ & 858 & 2.09093 & 2.48595 & 0.49996 & 26.03907 \\
\hline SIZE & 858 & 27.4949 & 1.44575 & 24.79102 & 32.20879 \\
\hline$A M R$ & 858 & 1.09325 & 1.13020 & 0.11481 & 13.38828 \\
\hline GRO & 858 & 0.62602 & 43.06105 & -972.6869 & 458.2154 \\
\hline$R O E$ & 858 & 0.17199 & 0.17183 & -1.2922 & 1.19603 \\
\hline TAX & 858 & 0.17326 & 0.14333 & -1.8707 & 1.64617 \\
\hline$G D P$ & 858 & 6.2209 & 0.63485 & 5.25 & 7.08 \\
\hline$I N F$ & 858 & 6.1545 & 4.7289 & 0.63 & 18.58 \\
\hline CREDIT & 858 & 17.4163 & 8.02107 & 8.85 & 37.7 \\
\hline
\end{tabular}

The study of this model is based on the panel data that describes two aspects of temporal and separate companies. The Pearson correlation matrix is used to examine the relationship between independent variables and multicollinearity problems. Table 2 shows the results of the correlation coefficient matrix. It can be concluded that there is no serious collinearity problem in model estimation as independent variables of consumer goods industry are not highly correlated with each other. According to Table 2, the correlation coefficients among independent variables of the model are relatively low, which means that multicollinearity is not a problem in the model under study.

Pooled OLS regression was conducted to estimate the relationship between independent variables and dependent variables. However, pooled OLS regression is a basic and simple model, search results are easily deviated. Thus, it has been proven that this model is ineffective in real-world situations because of correlation error and heteroscedasticity. Moreover, the multicollinearity phenomenon is examined based on the VIF coefficient (see Table 3). The results show that all the VIF coefficients are very low; this model does not exit the multicollinearity phenomenon. The fixed effect model

Table 2. Pearson correlation matrix

\begin{tabular}{|c|c|c|c|c|c|c|c|c|c|c|c|c|}
\hline Variable & $L D R$ & $T D R$ & TANG & $L I Q$ & SIZE & $A M R$ & GRO & $R O E$ & TAX & $G D P$ & INF & CREDIT \\
\hline$\angle D R$ & 1.0000 & - & - & - & - & - & - & - & - & - & - & - \\
\hline TDR & 0.1432 & 1.0000 & - & - & - & - & - & - & - & - & - & - \\
\hline TANG & 0.1995 & -0.0327 & 1.0000 & - & - & - & - & - & - & - & - & - \\
\hline$\angle I Q$ & -0.0026 & -0.552 & -0.145 & 1.000 & - & - & - & - & - & - & - & - \\
\hline SIZE & 0.4215 & 0.2113 & -0.024 & -0.142 & 1.000 & - & - & - & - & - & - & - \\
\hline$A M R$ & 0.2929 & -0.025 & 0.0315 & 0.1604 & 0.1292 & 1.000 & - & - & - & - & - & - \\
\hline$G R O$ & -0.0021 & 0.0070 & -0.004 & -0.015 & 0.0052 & -0.003 & 1.0000 & - & - & - & - & - \\
\hline$R O E$ & -0.0100 & -0.111 & -0.035 & -0.013 & 0.0575 & -0.140 & 0.0198 & 1.0000 & - & - & - & - \\
\hline TAX & 0.0000 & 0.0140 & -0.000 & -0.042 & 0.0950 & -0.072 & 0.0200 & 0.0403 & 1.0000 & - & - & - \\
\hline GDP & -0.0136 & 0.0210 & -0.017 & 0.0721 & 0.1502 & 0.0079 & -0.011 & -0.018 & -0.015 & 1.0000 & - & - \\
\hline INF & 0.0259 & -0.025 & -0.008 & -0.047 & -0.124 & -0.001 & 0.0033 & 0.0655 & -0.035 & -0.353 & 1.0000 & - \\
\hline CREDIT & 0.1021 & -0.006 & 0.0003 & 0.0142 & -0.113 & 0.0453 & 0.0199 & 0.1966 & -0.042 & -0.170 & -0.0833 & 1.0000 \\
\hline
\end{tabular}

Table 3. Regression results using Pooled OLS, REM, FEM, and FGLS

\begin{tabular}{|c|c|c|c|c|c|}
\hline Variable & VIF & Pooled OLS & FEM & REM & FGLS \\
\hline$T D R$ & 1.56 & $0.1185^{* * *}$ & $0.2020 * * *$ & $0.1724 * * *$ & $0.0537^{* * *}$ \\
\hline TANG & 1.05 & $0.2299 * * *$ & 0.2755 & $0.994 * *$ & $0.1624^{* * *}$ \\
\hline$\angle I Q$ & 1.59 & $0.091^{* * *}$ & $0.0103^{* * *}$ & $0.0101^{* * *}$ & $0.0110^{* * *}$ \\
\hline SIZE & 1.15 & $0.0463 * * *$ & $0.557 * * *$ & $0.0494 * * *$ & $0.0319^{* * *}$ \\
\hline$A M R$ & 1.10 & $0.0282 * * *$ & 0.0035 & $0.0083^{* *}$ & 0.0034 \\
\hline$G R O$ & 1.00 & -0.00001 & -0.00005 & -0.00004 & -0.0000 \\
\hline$R O E$ & 1.12 & -0.1270 & $-0.0559 * *$ & $-0.0457 * *$ & $-0.0189 * *$ \\
\hline TAX & 1.02 & -0.01299 & -0.0147 & -0.0133 & -0.0014 \\
\hline GDP & 1.22 & -0.0078 & $-0.0104^{* *}$ & -0.0086 & -0.0007 \\
\hline INF & 1.20 & $0.0031^{* * *}$ & $0.0042 * * *$ & $0.0037 * * *$ & $0.001^{* *}$ \\
\hline$C R E$ & 1.14 & $0.0028 * * *$ & $0.0033^{* * *}$ & $0.0031 * * *$ & $0.0019^{* * *}$ \\
\hline Cons & - & $-1.3267 * * *$ & $-1.5439 * * *$ & $-1.3858 * * *$ & $-0.9192^{* * *}$ \\
\hline$N$ & - & 853 & 853 & 853 & 853 \\
\hline$R$-sq & -... & 0.3224 & 0.298 & 0.330 & - \\
\hline Significance & - & $F(11,841)=36.37$ & $F(11,764)=11.49$ & Wald chi2 $(11)=172.56$ & $\begin{array}{l}\text { Wald chi2 }(11)= \\
238.46\end{array}$ \\
\hline Hausman Test & - & - & \multicolumn{2}{|c|}{$\operatorname{chi} 2(11)=33.13$ Prob $>$ chi $2=0.0001$} & $\ldots$ \\
\hline & & \multirow[b]{2}{*}{ - } & \multirow{2}{*}{\multicolumn{2}{|c|}{$\begin{aligned} \text { chi2 }(78) & =81210.81 \\
\text { Prob }>\text { chi2 } & =0.0000\end{aligned}$}} & \multirow{2}{*}{-} \\
\hline Wald Test & - & & & & \\
\hline
\end{tabular}

Note: $*, * *$, and $* * *$ denote significance levels at $1 \%, 5 \%$, and $10 \%$, respectively. 
(FEM) and random effect model (REM) are taken into consideration to estimate the determinants of corporate debt maturity structure. A $p$-value that is lower than the significant level of 5\% advocates the use of a fixed effects model, and vice versa, an insignificant $\mathrm{p}$-value indicates a random effects model is more appropriate. The Chi-square probability of the Hausman test is 0.0001 , thus, the estimation results of regression models should be derived from FEM estimation. Likewise, the sample data is checked using the Wald test, and prob $>$ chi $2=0.0000<0.05$; thus FEM has problems. The paper uses a feasible generalized least squares (FGLS) method to solve the FEM problem, since it assumes that the error is known rather than estimated. Consequently, the FGLS is an appropriate model to examine the factors affecting debt maturity of the consumer goods sector.

\section{DISCUSSION}

Table 3 shows that asset maturity insignificantly affects the debt maturity structure of the consumer goods industry. This means that asset maturity of this sector varies from company to company, since the asset structures of different companies are also quite different. It can be found that the volatility of asset maturity is fluctuated from the lowest value of 0.11 to the highest of 13.38 (see Table 1) among 78 listed companies. Since the portion of assets is diverse, these assets are financed by different sources. The consumer goods sector in Vietnam is associated with electronics, automobiles, food production, beverages, packaged goods, and clothing. This characteristic explains the reason why there is no impact of asset maturity on the enterprise debt maturity. Likewise, the interest rate volatility also represented no influence on the debt maturity structure of the consumer goods sector, since the interest rate that is charged by many creditors varies from electronics, automobiles, food production, beverages, packaged goods to clothing firms. The empirical results show that tax rate and GDP do not have any effect on the debt maturity structure of this industry. This result is in line with the findings of Deesomsak et al. (2009) who explored enterprises in Thailand. Many empirical studies did not find the relationship between macroeconomic determinants and debt maturity structure in the consumer goods sector.
Empirical results have shown that there is a positive and significant relationship between financial structure of a firm and debt maturity structure at a statistical level of $1 \%$. This result is in line with Ozkan (2002), Correia et al. (2014), Deesomsak et al. (2009), Fan et al. (2012), and González (2017). This impact has been explained by both economic theories and previous empirical results. As for the consumer goods sector, companies have maintained a high financial leverage with a mean of 0.5 , so they have intended to increase debt maturity.

The second factor, which was found to be positively significant for the debt maturity structure of a firm, is the TANG variable, which means that the higher the percentage of long-term assets, the longer the debt maturity. For the financial structure theories, the matching between long-term assets and long-term debt maturity is necessary to maintain the optimal capital structure in order to reduce financial risk. The correlation between the portion of non-current assets and debt maturity decisions has been mentioned in Ozkan (2002), Majumdar (2010), Alcock and Tan (2012), and González (2017).

A positive and significant influence of asset liquidity on corporate debt maturity in results is in line with the majority of previous empirical studies such as Ozkan (2002), Cai et al. (2008), Deesomsak et al. (2009), Majumdar (2010), and González (2017). As a result, the statistics presented at the $1 \%$ level are significant and underline that the higher the liquidity of companies' assets, the more firms intended to increase long-term debt in order to take advantage of tax shields. Due to high liquidity assets and the high collateral of assets, enterprises have more opportunities to assess a bank loan. Banks have also widened debt covenants for these firms.

Moreover, the empirical results notice that the larger the firm size by $1 \%$ of total assets, the higher the proportion of long-term debt. Examining the firm size, Ozkan (2002), Majumdar (2010), and González (2017) have shown the evidence of this relationship. This impact is also interpreted by the theories of Modigliani and Miller (1961) that bigger firms need to be financed by stable sources in the long run. In addition, it is easier for larger companies to assess long-term debts of different 
financial institutions. Due to the larger business scale, it is easier for them to have high collateral to ensure a bank loan.

The firm's profitability variable has a negative and significant signal at the 5\% threshold for debt maturity. In other words, firms that have a high return on equity will consider short-term debt instead of long-term debt. Taking shortterm debt may help a company to save the interest expense to increase profitability. With a low portion of long-term debt, companies do not take advantage of financial leverage in order to maximize shareholders' profitability. These findings are in line with the results of Ozkan (2000) who studied the sample of European countries.

In addition to the impact of microeconomic factors, debt maturity has also been influenced by macroeconomics. Inflation rate and credit growth have a significant positive influence on debt maturity at $5 \%$ and $1 \%$, respectively. These results are consistent with the characteristics of the Vietnamese financial market and have the same impact as Deesomsak et al. (2009), Wang et al. (2010), and Fan et al. (2012).

\section{CONCLUSION}

This paper examined the determinants affecting the debt maturity structure of 78 listed consumer goods firms in Vietnam from 2009 to 2019. The determinants of corporate debt maturity are estimated based on the influence of both microeconomic and macroeconomic factors. The empirical findings show that financial leverage, portion of tangible assets, asset liquidity, firm size, interest rate, and credit growth have a positive impact on debt maturity of the consumer goods industry. Whereas the profitability of a firm has a negative influence on the corporate debt maturity structure. These results recommend to internal managers that firms with high financial leverage consider long-term rather than short-term debt financing. Moreover, firms that have invested in a significant portion of tangible assets need to maintain a high percentage of long-term liabilities. The higher the liquidity of assets, the higher the percentage of long-term finance, since companies are easier to meet creditors' debt covenants. Finally, empirical results indicate that firm size was taken into account when determining the firm's debt structure. Furthermore, the paper points out the existence of interactions between inflation rate, credit growth and debt maturity. When banks pursue a policy of expanding their credit scale, firms also take advantage of this opportunity to increase long-term debt because they can take advantage of tax shields.

\section{AUTHOR CONTRIBUTIONS}

Conceptualization: Thi Van Trang Do.

Data curation: Thi Van Trang Do.

Formal analysis: Thi Van Trang Do.

Funding acquisition: Thi Van Trang Do.

Investigation: Thi Van Trang Do.

Methodology: Thi Van Trang Do.

Project administration: Thi Van Trang Do.

Resources: Thi Van Trang Do.

Software: Thi Van Trang Do.

Supervision: Thi Van Trang Do.

Validation: Thi Van Trang Do.

Visualization: Thi Van Trang Do.

Writing - original draft: Thi Van Trang Do.

Writing - review \& editing: Thi Van Trang Do. 


\section{REFERENCES}

1. Alcock, J., Finn, F., \& Tan, K. J. K. (2012). The determinants of debt maturity in Australian firms. Accounting \& Finance, 52(2), 313341. https://doi.org/10.1111/j.1467629X.2010.00397.x

2. Amal, M., Svensson, G., \& Terra, P. R. S. (2011). Determinants of corporate debt maturity in Latin America. European Business Review. https://doi. org/10.1108/09555341111097982

3. Antoniou, A., Guney, Y., \& Paudyal, K. (2006). The determinants of debt maturity structure: evidence from France, Germany and the UK. European Financial Management, 12(2), 161-194. https://doi.org/10.1111/j.13547798.2006.00315.x

4. Baker, M., \& Wurgler, J. (2002) Market timing and capital structure. The Journal of Finance, 57(1), 1-32. https://doi.org/10.1111/15406261.00414

5. Brick, I. E., \& Liao, R. C. (2017) The joint determinants of cash holdings and debt maturity: the case for financial constraints. Review of Quantitative Finance and Accounting, 48(3), 597-641. https:// doi.org/10.1007/s11156-016-0567-Z

6. Brick, I. E., \& Ravid, S. A. (1985). On the relevance of debt maturity structure. The Journal of Finance, 40(5), 1423-1437. https://doi. org/10.1111/j.1540-6261.1985 tb02392.x

7. Cai, K., Fairchild, R. \& Guney, Y. (2008). Debt maturity structure of Chinese companies. Pacific-Basin Finance Journal, 16, 268-297. https:// doi.org/10.1016/j.pacfin.2007.06.001

8. Correia, S., Brito, P., \& Brandão, E (2014). Corporate Debt Maturity - An international comparison of firm debt maturity choices (No. 544) Universidade do Porto, Faculdade de Economia do Porto. Retrieved from https://ideas.repec.org/p/por/ fepwps/544.htm

9. Deesomsak, R., Paudyal, K. \& Pescetto, G. (2009). Debt maturity structure and the 1997 Asian financial crisis. Journal of Multinational Financial Management, 19(1), 26-42. https://doi.org/10.1016/j.mulfin.2008.03.001
10. Diamond, D. W. (1991). Debt maturity structure and liquidity risk. The Quarterly Journal of Economics, 106(3), 709-737. https:// doi.org/10.2307/2937924

11. Fama, E. F. (1990). Contract costs and financing decisions. Journal of Business, S71-S91. Retrieved from https://www.jstor.org/ stable $/ 2353261$ ?seq $=1$

12. Fan, J., Titman, S., \& Twite, G. (2012). An internationa comparison of capital structure and debt maturity choices. Journal of Financial and Quantitative Analysis, 47(1), 23-56. https://doi. org/10.1017/S0022109011000597

13. González, V. M. (2017). Firm and country determinants of debt maturity: New international evidence. International Finance, 20(3), 256-270. https://doi. org/10.1111/infi.12116

14. Jensen, M. C., \& Meckling, W. H. (1976). Theory of the firm: Managerial behavior, agency costs and ownership structure. Journal of Financial Economics, 3(4), 305-360. https://doi.org/10.1016/0304405X(76)90026-X

15. Leland, H. E., \& Toft, K. B. (1996). Optimal capital structure, endogenous bankruptcy, and the term structure of credit spreads. The Journal of Finance, 51(3), 987-1019. https://doi. org/10.1111/j.1540-6261.1996. tb02714.x

16. Lemma, T. T., \& Negash, M. (2012). Debt maturity choice of a firm: evidence from African countries. Journal of Business and Policy Research, 7(2), 60-92.

17. Majumdar, R. (2010). The Determinants of Corporate Debt Maturity: A Study of Indian Firms. IUP Journal of Applied Finance, 16(2).

18. Modigliani, Modigliani, F., \& Miller M. (1963). Corporate income taxes and the cost of capital: A correction. American Economic Review, 53, 433443. Retrieved from https://www. jstor.org/stable/1809167?seq=1

19. Myers, S. C. (1977). Determinants of corporate borrowing. Journal of Financial Economics, 5(2), 147-175. https://doi.org/10.1016/0304405X(77)90015-0
20. Ngo, V. T., \& Le, T. L. (2021). Factors Influencing Corporate Debt Maturity: An Empirical Study of Listed Companies in Vietnam. The Journal of Asian Finance, Economics and Business, 8(5), 551-559. https:// doi.org/10.13106/jafeb.2021.vol8. no5.0551

21. Omar, K. G., \& Al-Tahat, S. (2020). Determinants of capital structure: evidence from Jordanian service companies. Investment Management and Financial Innovations, 17(2), 364-376. https://doi.org/10.21511/ imfi.17(2).2020.28

22. Ozkan, A. (2000). An empirical analysis of corporate debt maturity structure. European Financial Management, 6(2), 197-212. https:// doi.org/10.1111/1468-036X.00120

23. Ozkan, A. (2002). The determinants of corporate debt maturity: evidence from UK firms. Applied Financial Economics, 12(1), 19-24. https://doi. org/10.1080/09603100110102691

24. Pour, E. K., \& Lasfer, M. (2019). Taxes, governance, and debt maturity structure: International evidence. Journal of International Financial Markets, Institutions and Money, 58, 136-161. https://doi. org/10.1016/j.intfin.2018.09.011

25. Robichek, A. A., \& Myers, S. C. (1966). Problems in the theory of optimal capital structure. Journal of Financial and Quantitative Analysis, 1-35. https://www.jstor.org/ stable/2329989? seq=1

26. Ross, S. A. (1977). The Determination of Financial Structure: The Incentive-Signalling Approach. The Journal of Economics, 8(1), 23-40. Retrieved from https:// www.jstor.org/stable/3003485?seq=1

27. Wang, Y., Sun, Y., \& Lv, Q. (2010). Empirical study on the debt maturity structure based on the macroeconomic variables. International Journal of Business and Management, 5(12), 135-140.

28. Warner, J. B. (1977). Bankruptcy, absolute priority, and the pricing of risky debt claims. Journal of Financial Economics, 4(3), 239-276. https://doi.org/10.1016/0304405X(77)90002-2 